\title{
Biotechnological Applications of Halophilic Pigments - An Overview
}

\author{
D. Manjula ${ }^{1}$, P. Jeevitha ${ }^{1}$, I. Ramya ${ }^{1}$, J. Hemapriya ${ }^{1}$ and Ashwini Ravi ${ }^{2 *}$ \\ ${ }^{1}$ Department of Microbiology, DKM College for Women, Vellore, Tamil Nadu - 632001, India \\ ${ }^{2}$ Department of Biotechnology, Thiruvalluvar University, Vellore, Tamilnadu-632115, India
}

*Corresponding author

\begin{tabular}{l}
\hline Ke y w o r d s \\
Bacterioruberin, \\
Carotene, \\
Halophiles, \\
Pigments, Salinity \\
\hline Article Info \\
\hline $\begin{array}{l}\text { Accepted: } \\
\text { 25 June } 2018 \\
\text { Available Online: } \\
\text { 10 July } 2018\end{array}$ \\
\hline
\end{tabular}

Keywords

Bacterioruberin,

Carotene,

Halophiles,

Pigments, Salinity

10 July 2018

\section{A B S T R A C T}

Halophiles are group of microorganisms known for their ability to survive in conditions of extreme salinity and also temperature. They fall under all three domains of life and categorized into three groups based on the requirement of $\mathrm{NaCl}$ for their survival as slight halophiles, moderate halophiles and extreme halophiles. Their natural behavior of their existence in regions of high salinity has provided them with number of novel elements and mechanism which can be used in several areas. One among their important component is their pigments. The present review deals with the various types of pigments produced by halophiles and their applications in various field of biotechnology and medicine.

\section{Introduction}

Halophile is a Greek derived word in which 'halo' means 'salt' and 'philos' means 'loving'. Halophilic organisms are salt loving organisms that thrive well in various ranges of salt concentrations (Sarma and Sarma, 2012). The halophilic organisms are classified according to Kushner as slight halophiles, moderate halophiles and extreme halophiles.
Slight Halophiles lives in the salt concentration of $1-3 \% \mathrm{NaCl}$ ranging from $0.2 \%-0.85 \%$. Moderate Halophiles lives in the $\mathrm{pH}$ range of $3-15 \% \mathrm{NaCl}$ concentration where as extreme Halophiles require 20-30 \% $\mathrm{NaCl}$ range. Apart from these three there is halotolerant organism which grows in salt concentration of less than $1 \% \mathrm{NaCl}$ but will tolerate high salt concentrations up to $2.5 \mathrm{M}$ (Moreno, 2013). 
The halophilic organisms are found in all three domains of classification i.e., Bacteria, Archaea and Eucarya (Shivanand and Mugeraya, 2011). The presence of $\mathrm{NaCl}$ over the accepted limit is critical for any organism to survive as it causes high osmolarity in the environment. As a result the organism loses its water content to the surrounding environment. To prevent this, halophiles carry over several mechanisms to equate the osmolarity in the inside and outside environment (Sarma and Sarma 2012). The halophiles are also gaining industrial importance because of their greater use in several manufacturings from food to textiles.

The halophilic organisms produce several useful complexes such as compatible solutes, enzymes like protease (Vidyasagar et al., 2009), chitinase, lipases (Singh et al., 2010) glycosyl hydrolase, $\beta$ galactosidase, amylase, restriction enzymes, esterase (Li et al., 2012) and lipase which is used in detergent and food industries, baking industry, degradation of xylan, removal of fructose, textile industries, laundary detergents, as a biocatalysts and a biotechnological tool. On the environmental basis they play a significant role in degradation of heavy oils (Hao et al., 2009), azo dyes, tannery waste treatment, prevents nitrate pollution and shows tolerant to heavy metal toxicity and its growth were detected in acid mine drainages, waste water treatment and aquarium biofilters (Sarma and Coker, 2010; Calderon et al., 2013). Apart from these they also aids in the production of biofuel and PAH (Calderon et al., 2013). Medically it has been used in the production of gas vescicles and liposome in vaccine development and production of halocins and microhalocins which is an antibacterial agent. Including all these they also produce $\beta$ carotene and the Bacteriorhodopsin is used as light driven photon pump in several optical mechanics (Shivanand and Mugeraya, 2011 Calderon et al., 2013).

\section{Applications of Halophiles}

In recent years, the halophilic microorganisms have been concentrated for various industrial applications because of their ability to tolerate extreme environmental conditions. The halophilic enzymes being unaffected by extremes of salinity and $\mathrm{pH}$ changes have been used in several industrial processes (Gomez and Steiner 2004; Vijayanand et al., 2009). The biomolecules such as compatible solutes and carotenoids produced by them also show several applications in various industries. The ability of photochromic protein bacteriorhodopsin produced by Haloarchaea Halobacterium salinarum has been experimented to produce Dye sensitized solar cells (Ashwini et al., 2017). The present review deals with essentials of halophilic pigments in various applications.

\section{Halophilic pigments}

Halophiles produce Carotenoids as their predominant pigments. The major carotenoid compounds produced by halophilic archaea and bacteria are $\beta$ - carotenoid, Lycopene, Phytoene, haloxanthin, Bacterioruberin (monoanhydrobacteriorubeerin,

bisanhydrobacterior- -buerin, epoxymonoanhydrobacterioruberin) (Fang et al., 2010; Mandelli et al., 2012). Though several carotenoids such as lycopene, phytoene and haloxanthin are produced by halophiles, the pigment $\beta-$ carotene, bacteriorhodopsin and bacterioruberin are explored by various research communities for application in several fields.

\section{$\beta$ - carotene}

The carotenoid pigment $\beta$ - carotene (Fig 1) is majorly produced by the halophilic algae Dunaliella salina. It is a flagellated species that grows in salinity and withstands high temperature of about $40{ }^{\circ} \mathrm{C}$. The ability of the 
organism to withstand these unusual conditions and also their capability in producing carotenoid makes it an efficient candidate for the industrial production of $\beta-$ carotene.

It is the main carotenoid accumulated by the organism and is the carotenoid pigment that accounts for about $20 \%$ of total carotenoids. These carotenoids accumulate in globules located in interthylakoid space within the chloroplast of Dunaliella salina.

Apart from $\beta$ - carotene, the organism also produces other pigments such as astaxanthin and cantaxanthin (Borowitzka et al., 1984; Amotz 1999; Hosseini and Shariati, 2010).

$\beta$ - carotene has been extensively used in food applications and those extracted from the organism were found to have several medicinal applications such as anti-viral activity, anti-cancerous activity, antiinflammatory activity, anti-allergic activity, anti-diabetic activity, hepato-protective activity, for improving eye sight and as detoxifier (Arun and Singh 2016).

\section{Bacteriorhodopsin}

Bacteriorhodopsin is a $26 \mathrm{KDa}$ protein (Fig 2) that is first recognized in halophilic archaea Halobacterium salinarium formerly called as Halobacterium halobium (Blaurock and Stoeckenius 1971; Mathies et al., 1991). The photochromic protein acquired the name
Bacteriorhodopsin based on its similarities in absorption of light, chromophore, schiff's base, composition of amino acids and sequence of reactions with the visual rhodopsin found in mammals. The cell membrane that holds bacteriorhodopsin is called as "purple membrane" due to the presence of pigment as patches (Oesterhelt and Hess 1973; Ormos et al., 2002) and constitutes a retinal based photosynthetic system in the presence of sunlight under anoxious circumstances (Blaurock and Stoeckenius 1971).

The protein contains 248 amino acids which are bound to retinal chromophore at Lys 216 by a schiff's base linkage (Khorana et al., 1979; Ovchinikov et al., 1979).

Two dimensional crystal lattice view through electron microscope of bacteriorhodopsin revealed that the protein exists as trimers in purple membrane and each monomer consists of seven alpha helices running nearly perpendicular to the surface of membrane at an angle from $0^{\circ}$ to $20^{\circ}$ (Henderson and Unwin 1975).

The pigment acts as a green light driven photon pump of wavelength $500-650 \mathrm{~nm}$ that converts light energy into chemical energy. This converted light driven energy is utilised by halobacterium for the production of ATP, amino acid uptake and locomotion (Oesterhelt and Hess 1973; Oesterhelt 1976; Stoeckenius and Bogomolni 1982).

Fig.1 Structure of $\beta$ - carotene (Mol view)

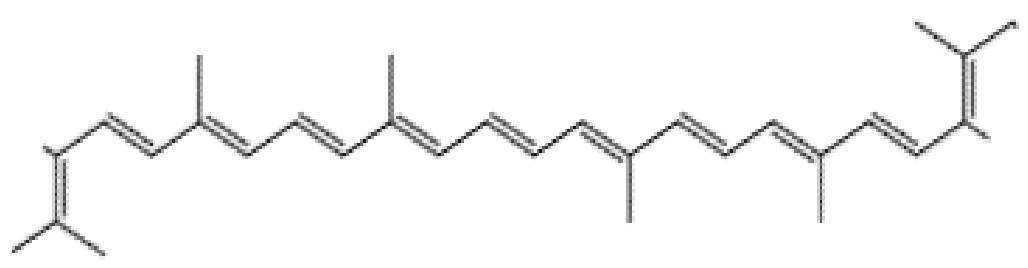


Fig.2 Structure of bacteriorhodopsin (PDB)

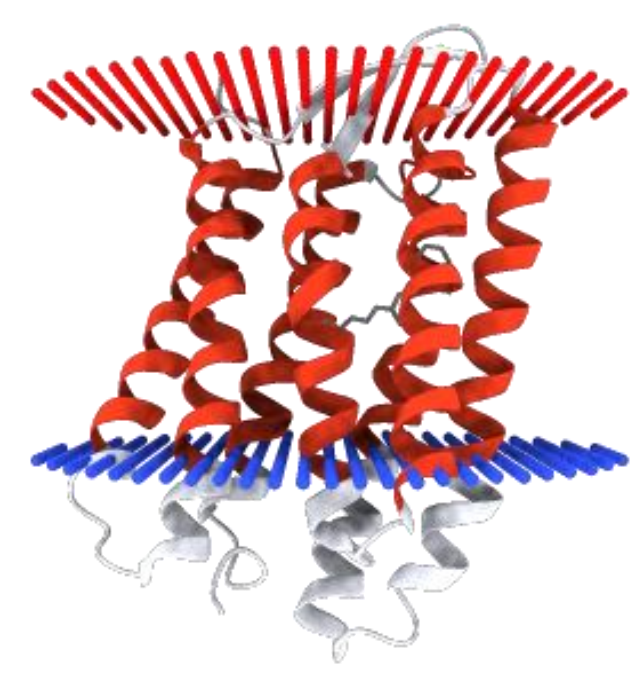

Fig.3 Structure of bacterioruberin (Mol view)

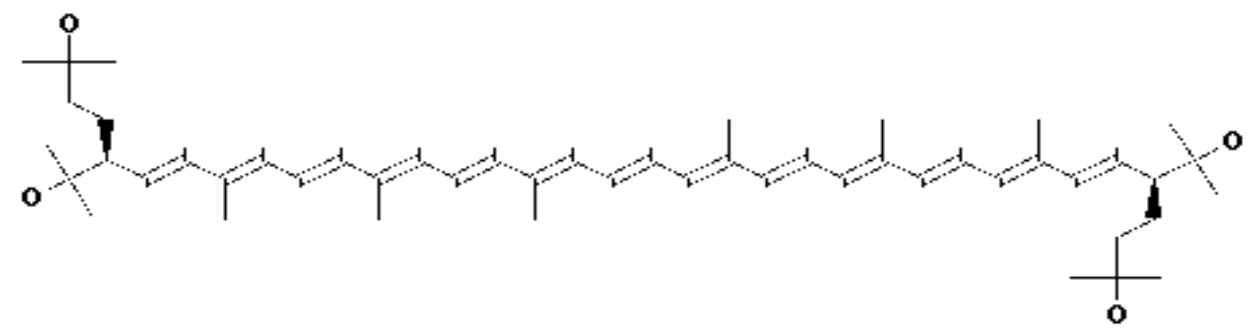

Simulation of bacteriorhodopsin by green light initiates photonic cascade during which protons of 10,000 times higher folds is produced within the cell (Subramaniam et al., 1993; Haupts et al., 1997; Haupts et al., 1999). This reversible cascade lasts for $1 \mathrm{ps}$ to $3 \mathrm{~ms}$ when light hits bacteriorhodopsin at a range of $250 \mathrm{mv}$. The proton avalanche created during the cascade makes cell more alkaline than the outside environment and generates ATP for cell's survival even in deprived environmental conditions (Haupts et al., 1997; Kuhlbrandt 2000; Slonczewski and Foster 2011). Research on Bacteriorhodopsin initiated with a quest of understanding its nature and proton pumping cycle. But in later years, it was considered as a model system for $\mathrm{G}$ protein coupled receptor (GPCR) and membrane protein folding studies (Henderson et al., 1990). In addition to these, the phototactic ability of bacteriorhodopsin has also enhanced its applications in several fields such as optical memories, real-time holographic media, photovoltaic cells and artificial retinas (Chen and Birge 1993; Stuart et al., 1996; Birge et al., 1999; Hampp et al., 2000). The necessity of bacteriorhodopsin for its photo tactic ability is increasing every day and this review deals with applications of bacteriorhodopsin in various optical and electronic devices (Ashwini et al., 2017).

\section{Bacterioruberin}

Bacterioruberin (Fig 3) is a carotenoid pigment produced by halophilic archaea such as Halobacterium salinarum strains NRC-1 and R1, Halorubrum sodomense, Haloarcula 
vallismortis, Haloarcula japonica, Halococcus morrhuae, Haloferax volcanii etc. (Mandelli et al., 2012; Jehlicka 2013; Yatsunami et al., 2014).. The bacterioruberin is synthesized with geranyl geranyl phosphate as the initial precursor and the pathway deviates from lycopene to monoanhydrobacterioruberin, bisanhydrobacterioruberin finally giving the product bacterioruberin. The pigment bacterioruberin acts as antioxidant and during the recent years it has found to be an integral part of ion channel protein of archaea halorhodopsin and archaearhodopsin.

The synthesis of bacterioruberin by Halobacterium salinarum was found to be initiated from Geranyl geranyl phosphate and during the formation of lycopene the pathway gets divided into two where lycopene gets converted to retinal, bacterioopsin and bacteriorhodopsin or it gets converted to monohydrobacterioruberin,

bisnahydrobacteriorube- -rin finally producing bacterioruberin. The pigment bacterioruberin is now been explored for its application in photovoltaics and optoelectronic (Ronnekleiv et al., 1995; Bidle et al., 2007).

The present review has explained the pigments of halophilic microorganisms and their application in several fields. These pigments has also been explored around the world by several researchers around the world for their other applications and improvising them in present field.

\section{References}

Ashwini R, Vijayanand S, Hemapriya J. Photonic potential of Haloarchaeal pigment bacteriorhodopsin for future electronics. J Curr Microbiol 2017; DOI 10.1007/s00284-017-1271-5.

Ben-Amotz A (1999) Dunaliella $\beta$-carotene. From science to commerce. In: Seckbach
$\mathbf{J}$ (ed) Enigmatig microorganisms and life in extreme environments. Kluwer Academic, Dordrecht, The Netherlands, pp 399-410

Bidle KA, Hanson TE, Howell K, Nannen J. (2007) HMG-CoA reductase is regulated by salinity at the level of transcription in Haloferax volcanii. Extremophiles 11(1): 49-55.

Birge RR, Gillespie NB, Izaguirre EW, Kusnetzow A, Lawrence AF, Singh D, Song QW, Schmidt E, Stuart JA, Seetharaman S et al., (1999) Biomolecular electronics: protein-based associative processors and volumetric memories. J Phys. Chem. B 103:1074610766.

Blaurock AE, Stoeckenius W. (1971) Structure of the purple membrane. Nat. New Biol. 233: 152-155.

Borowitzka LJ, Borowitzka MA, Moulton T (1984) Mass culture of Dunaliella: from laboratory to pilot plant. Hydrobiology 117:115-121

Fang XQ, Liu JX, Gupta V. (2013) Fundamental formulations and recent achievements in piezoelectric nanostructures: a review. Nanoscale. 5: 1716. DOI: http://dx.doi.org/10.1039/c2nr33531j.

Fendrihan, S., Legat, A., Marion Pfaffenhuemer, Claudia Gruber, Gerhard Weidler, Friedrich Gerbl, and Helga StanLotter, Extremely halophilic archaea and the issue of long-term microbial survival, Europe PMC Funders Group,5(2-3), 2006, 203-218.

Gómez J, Steiner W. The biocatalytic potential of extremophiles and extremozymes. Food Technol Biotechnol 2004; 2: 223 235.

Hampp N. (2000) Bacteriorhodopsin: mutating a biomaterial into an optoelectronic material. Appl. Microbiol. Biotechnol. 53: 633-639.

Haupts U, Tittor J, Bamberg E, Oesterhelt D. (1997) General concept for ion translocation by halobacterial retinal 
proteins: the isomerization/switch/transfer (IST) model. Biochem. 36(1): 2-7.

Haupts U, Tittor J, Oesterhelt D. (1999) Closing in on bacteriorhodopsin: progress in understanding the molecule. Annu. Rev. Biophys. Biomol. Struct. 28: 367-399.

Henderson R, Baldwin JM, Ceska TA, Zemlin F, Beckmann E, Downing KH. (1990) Model for the structure of bacteriorhodopsin based on highresolution electron cryo-microscopy. $J$ Mol. Biol. 213(4): 899-929.

Henderson R, Unwin PNT. (1975) Threedimensional model of purple membrane obtained by electron microscopy. Nature. 257(5521): 28-32.

Hosseini TA, Shariati M (2010) Dunaliella biotechnology: methods and applications. J Appl Microbiol 107:14-35

http://molview.org/

http://www.rcsb.org/structure/1S51

Jehlicka J, Edwards HGM, Oren A. (2013) Bacterioruberin and salinixanthin carotenoids of extremely halophilic Archaea and Bacteria: a Raman spectroscopic study. Spectrochim. Acta Part A. 106: 99-103. doi:10.1016/j.saa.2012.12.081.

Kadiya Calderón, Alejandro GonzálezMartínez, Cinta Gómez-Silván, Francisco Osorio, Belén Rodelas and Jesús González-López, Archaeal Diversity in Biofilm Technologies Applied to Treat Urban and Industrial Wastewater: Recent Advances and Future Prospects, International journal of molecular sciences, 2013, 14, 18572-18598.

Khorana HG, Gerber GE, Herlihy WC, Gray CP, Ander egg RJ, Nihei K, Biemann K. (1979) Amino acid sequence of bacteriorhodopsin. Proc. Natl Acad. Sci. USA 76: 5046-5050.

Kuhlbrandt W. (2000) Bacteriorhodopsin: the movie news and views. Nature 406: 569 570 .

Makarova and Koonin, Domain Archaea, Genome Biology 2003, Volume 4, Issue 8 , Article 115, 1-52.
Malashetty vidyasagar, S. Prakash, Vineet Mahajan, Yogesh S. Shouche, K. Sreeramalu, Purification and characterization of extreme halothermophilic protease from a halophilic bacterium Chromohalobacter sp. TVSP101, Brazilian Journal of Microbiology, 2009, 40 (1), 1-12.

Mandelli F, Miranda VS, Rodrigues E, Mercadante AZ. (2012) Identification of carotenoids with high antioxidant capacity produced by extremophile microorganisms. World J. Microbiol. Biotechnol. 28(4): 1781-1790.

Mathies RA, Lin SW, Ames JB, Pollard WT. (1991) From femtoseconds to biology: mechanism of bacteriorhodopsin's lightdriven proton pump. Annu Rev Biophys. Biophys. Chem. 20: 491-518.

Moreno ML, Dolores Pérez, María Teresa García and Encarnación Mellado, Halophilic Bacteria as a Source of Novel Hydrolytic Enzymes, Life 2013, 3, 38-51.

Neelam Arun and D.P. Singh, A review on pharmacological applications of halophilic alga Dunaliella, Indian Journal of Geo-Marine Science, 45 (3), 2016, pp. 440-447

Oesterhelt D, Hess B. (1973) Reversible photolysis of the purple complex in the purple membrane of Halobacterium halobium. Eur. J Biochem. 40: 453-463.

Oesterhelt D. (1976) Bacteriorhodopsin as an example of a light driven proton pump. Angew. Chem. Int. Ed Engl. 15(1): 17-24.

Ormos P, Fabian L, Oroszi L, Wolff EK, Ramsden JJ, Der A. (2002) Protein-based integrated optical switching and modulation. App. Phys. Lett. 80(21): 4060-4062.

Ovchinikov Yu A, Abdulaev NG, Yu Feigina M, Kiselev AV, Lobanov NA. (1979). The structural basis of the functioning of bacteriorhodopsin: an overview. FEBS Lett. 100: 219-224.

Priya dassarma, james a. Coker, valerie huse, and shiladitya dassarma university of maryland, baltimore, Maryland, 
Halophiles, Industrial applications, 2010, $1-10$.

Ronnekleiv M, Liaaen-Jensen S. (1995)

Bacterial Carotenoids 53*, C50Carotenoids 23; Carotenoids of Haloferax volcanii versus other Halophilic Bacteria. Biochem. Syst. Ecol. 23: 627-734.

Ruixia Hao and Anhuai Lu, Biodegradation of Heavy oils by halophilic bacterium, Natural Sciences, 19, 2009, 997-1001.

Sarma SD and Sarma PD, University of Maryland, Baltimore, Maryland, USA, Halophiles, eLS \& 2012, John Wiley \& Sons, Ltd.www.els.net, 1-11.

Shivanand $\mathrm{P}$ and Mugeraya G, Halophilic bacteria and their compatible Solutes osmoregulation and potential Applications, Current Science, 100 (10), 2011, 1516-1521

Singh, S.P., M.K. Purohit, V.H. Raval, S. Pandey, V.G. Akbari and C.M. Rawal, Capturing the potential of haloalkaliphilic bacteriafrom the saline habitats through culture dependant and metagenomic approaches, Current Research, Technology and education topics in Applied Microbiology and Microbial Biotechnology, Formatex 2010, 81-86.

Slonczewski J, Foster JW. (2011) Microbiology: an evolving science. $W W$ Norton, New York.

Stoeckenius W, Bogomolni RA. (1982) Bacteriorhodopsin and related pigments of halobacteria. Annu. Rev. Biochem. 52: 587-616

Stuart JA, Tallent RJ, Tan EHL, Birge RR. (1996) Protein based volumetric memories. Int'l nonvolatile memory technology conference. doi:10.1109/NVMT.1996.534668.

Subramaniam S, Gerstein M, Oesterhelt D, Henderson R. (1993) Electron diffraction analysis of structural changes in the photocycle of bacteriorhodopsin. EMBOJ. 12(1): $1-8$.

Vijayanand S, Hemapriya J, Selvin J, Kiran S. Production and optimization of haloalkaliphilic protease by an extremophile - Halobacterium Sp, JS1, isolated from thalassohaline environment. African J Basic Appl Sci 2009; 1(3-4): 49 $-54$.

Xin Li, Hui Yung $\mathrm{Yu}$ and Yi Feng Lin, Purification and characterization of an extracellular esterase from a moderately halophilic bacterium Halobacillus sp. Strain LY5, African Journal of Biotechnology, 2012, 11 (23), 6327-6334. Yatsunami R, Ando1 A, Yang Y, Takaichi S, Kohno1 M, Matsumura Y, Ikeda H, Fukui T, Nakasone K, Fujita N, Sekine M, Takashina T, Nakamura S. (2014) Identification of carotenoids from the extremely halophilic archaeon Haloarcula japonica. Front. Microbiol. 5(100): 1-5.

\section{How to cite this article:}

Manjula D., P. Jeevitha, I. Ramya, J. Hemapriya and Ashwini Ravi. 2018. Biotechnological Applications of Halophilic Pigments - An Overview. Int.J.Curr.Microbiol.App.Sci. 7(07): 4392-4398. doi: https://doi.org/10.20546/ijcmas.2018.707.512 